УДК $[630 * 45](571.16)$

DOI: $10.37482 / 0536-1036-2020-3-24-41$

\title{
RECONSTRUCTION OF STAND HISTORY AND IMPACT EVALUATION OF AN INVASIVE BARK BEETLE IN SIBERIAN FIR FORESTS WITH THE HELP OF SPATIAL STRUCTURE ANALYSIS
}

N.M. Debkov ${ }^{1,2}$, Candidate of Agriculture, Researcher; ResearcherID: H-1146-2019,

ORCID: https://orcid.org/0000-0003-3791-0369

A. Gradel 3 ,4, PhD, Forestry Consultant; ResearcherID: AAK-1808-2020,

ORCID: https://orcid.org/0000-0002-6298-4151

A.A. Aleinikov, Candidate of Biology, Senior Research Scientist; ResearcherID: $\underline{\text { K-1285-2017, }}$ ORCID: https://orcid.org/0000-0002-5715-8488

${ }^{1}$ Institute of Monitoring of Climatic and Ecological Systems of the Siberian Branch of the Russian Academy of Sciences, prosp. Akademicheskiy, 10/3, Tomsk, 634055, Russian Federation; e-mail: nikitadebkov@yandex.ru

${ }^{2}$ National Research Tomsk State University, prosp. Lenina, 36, Tomsk, 634055, Russian Federation; e-mail: nikitadebkov@yandex.ru

${ }^{3}$ International Forestry Consultancy Gradel, Jakobstraße 12, 02826 Görlitz, Germany; e-mail: agradel@jpberlin.de

${ }^{4}$ Faculty of Forest Sciences and Forest Ecology, Georg-August-Universität Göttingen, Büsgenweg 5, 37077 Göttingen, Germany

${ }^{5}$ Center for Forest Ecology and Productivity of the Russian Academy of Sciences, ul. Profsoyuznaya, 84/32, str. 14, Moscow, 117997, Russian Federation; e-mail: aaacastor@gmail.com

The most devastating insect invasion of forest ecosystems in Russia is the recent mass reproduction of the four-eyed fir bark beetle (Polygraphus proximus Blandf.) in southern Siberian fir (Abies sibirica Ledeb.) forests. The objective of our research was to study the spatial structure of fir forests and their change under the impact of the four-eyed fir bark beetle in its secondary (invasive) distribution range. We selected two fir stands located near the villages of Itatka and Malinovka in the Tomsk region. Both stands represent natural ripe succession forests on sites that previously experienced logging activities, which were triggered by settlement activities in the second half of the nineteenth century. We used Field-Map technology for gathering non-spatial and spatial stand data. The analysis showed that height, diameter and radial increment of fir trees, killed or severely weakened by attacks of the four-eyed fir bark beetle, were significantly lower than that of healthy individuals. The social status of fir trees, seriously attacked or already killed by Polygraphus proximus was indicated by the $U_{i}$ index as moderately suppressed. In contrast to the distribution pattern of living firs, the pattern of dead or severally weakened firs killed by the four-eyed fir bark beetle was significantly clumped over short distances (sample plots (SP) Itatka and Malinovka). This finding coincides with visual observations in other stands, that dead trees are grouped to some extent. However, the hypothesis of spatial independence of the tree positions of living and dead firs was accepted for both plots.

Funding: The research was funded by the Russian Foundation for Basic Research and the government of Tomsk region, grant No. 16-44-700782, and carried out as part of a state assignment of the Center for Forest Ecology and Productivity of the Russian Academy of Sciences (No. AAAA-A18-118052400130-7).

For citation: Debkov N.M., Gradel A., Aleinikov A.A. Reconstruction of Stand History and Impact Evaluation of an Invasive Bark Beetle in Siberian Fir Forests with the Help of Spatial Structure Analysis. Lesnoy Zhurnal [Russian Forestry Journal], 2020, no. 3, pp. 24-41. DOI: 10.37482/0536-1036-2020-3-24-41 
Keywords: insect invasions, Polygraphus proximus Blandf., Abies sibirica Ledeb., tree mortality, spatio-temporal characteristics.

\section{Introduction}

The beginning of the twenty-first century is accompanied by massive cases of invasions of alien biota [6]. In addition long-term modeling shows an increase in the number of invasions [5]. This also applies to forest ecosystems. The economic, environmental and social consequences of exposure to invaders [11, 13, 24] allow us to consider them as disturbance forces and factors of forest-forming processes. The most devastating invasions in Russia are invasions of the box tree moth $C y$ dalima perspectalis [1], emerald ash borer Agrilus planipennis [43] and four-eyed fir bark beetle Polygraphus proximus [28]. The latter one is also denoted as the Far Eastern bark beetle invasion due to its original distribution area. In terms of scale and risks for Russian forest management, the invasion of this insect is the most significant in Siberia, where it first occurred in 2008 [28]. According to Kharuk et al. [26] the progressive spread of the aggressive beetle Polygraphus proximus in Siberia is associated with the impact of climate change. Its mass reproduction is promoted by the weakening of forests by water stress due to the increasing climate aridisation [25].

Along with traditional research methods, spatial structure analysis is increasingly used for solving complex ecological issues [17, 27, 34, 36], which allows to make predictions of ecosystem dynamics [22]. Spatial forest structure has been considered as an indicator of ecological stability, biodiversity, competition processes and forest ecosystem functioning [12, 30, 33, 39, 44, 46], and determines microclimatic conditions, the provision of resources and characteristic features of forest habitats $[17,30]$. The main parameter of spatial forest structure is the tree distribution pattern $[17,42]$. Recently, the impact of different harvest events on horizontal tree distribution patterns has been studied in different conifer stands in the region, specifically in north China and Mongolia [18, 31]. However, there are hardly any studies that assessed or monitored the impact of an invasive bark beetle species on the spatial structure of boreal conifer stands. To our knowledge, there are no studies that analysed the impact of invasive bark beetles on the spatial structure in Russian forests. Spatial structure transformation in forests exposed to invasive organisms is of particular interest.

In this regard, our aim was to study the spatial structure of fir forests and their change under the impact of the Far Eastern bark beetle (Polygraphus proximus Blandf.) in the secondary range of distribution in Tomsk region. We specifically researched the preferences of the bark beetle in terms of size and social status of trees and how the infestation changes the forest structure. We hypothesised that the bark beetle attacks and kills smaller, older and less dominant trees and that trees are not randomly attacked, but are grouped within the stand.

\section{Materials and methods}

We selected two fir forest stands in Tomsk region in the Kornilovskoye lesnichestvo (forest unit). Both stands have been subjected to recent infestation by Polygraphus proximus and are situated in the vicinity of the villages of Itatka and 
Malinovka (Fig. 1). In each stand, we established one permanent large-sized sample plot (SP Itatka and SP Malinovka). The SPs differ in the succession stage and utilisation history. The forest stand near the village of Itatka was subjected to selective logging, and near the village of Malinovka, to clear-cutting.

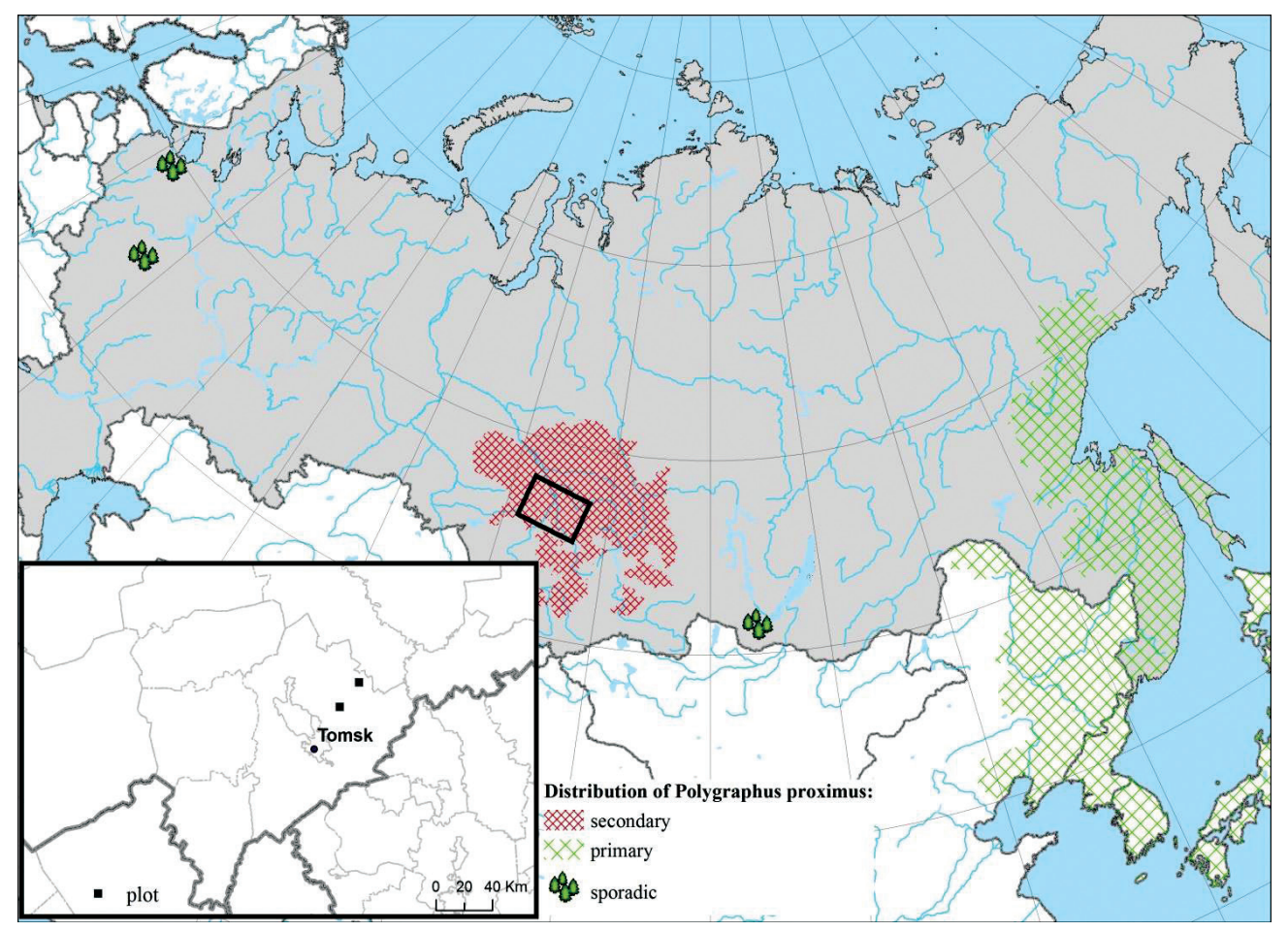

Fig. 1. Study area

Data assessment

On each plot we assessed the following data: tree species, diameter at breast height (DBH), tree height, tree age, crown length, crown projection area and radial growth of every tree with a minimum DBH of $6 \mathrm{~cm}$. We used Field-Map technology, which combines a flexible real-time GIS software Field-Map with electronic equipment for mapping and dendrometric measurements. Additionally, the tree status of each fir tree was evaluated according to a six-point scale, which describes the impact of Polygraphus proximus on Abies sibirica. The calculation of the average weighted category of tree status was performed by the following formula [28]:

$$
\mathrm{AWTS}=\frac{\sum g_{1}+\sum g_{2}+\sum g_{3}+\sum g_{4}+\sum g_{5}+\sum g_{6}}{\sum G},
$$

where AWTS - the average weighted category of tree status in the respective stand; $\Sigma g_{1}, \Sigma g_{2}$, $\Sigma g_{3}, \Sigma g_{4}, \Sigma g_{5}, \Sigma g_{6}$ - the sums of the basal areas of healthy, weakened, severely weakened, dead and dead standing trees (fresh and old), respectively; $\Sigma G$ - the sum of basal areas of all fir trees in the sample plot (RS).

Dead wood assessment was carried out according to the following classification: 0 - not yet decomposed; 1 - recently deceased: bark poorly separated, wood without rot; 2 - slightly decomposed: bark easily breaks off and disappears, rot is up to $25 \%$ of 
the diameter; 3 - moderately decomposed: rot is up to $50 \%$ of the diameter, the core of the trunk is solid; 4 - highly decomposed: rot is $50-75 \%$, the core of the trunk is solid; 5 -almost completely decomposed: rot is more than $75 \% ; 6$ - completely decomposed (humification of wood). See Table 1 for an overview of both plots.

Data analysis

Measurements were carried out using the Field-Map technology system for the computer-aided field data collection. Core sampling was performed with an incremental borer (length of $400 \mathrm{~mm}$; diameter of $5.15 \mathrm{~mm}$, Haglof, Sweden). In rare cases, we obtained cookies with the help of a Husqvarna 365 chain saw. The width of the tree rings was measured using the LINTAB-5 complex with the TSAP software package [37] with an accuracy of $0.01 \mathrm{~mm}$.

Table 1

Characteristics of the fir stands on the sample plots, 2018

\begin{tabular}{|c|c|c|c|c|c|c|c|}
\hline $\begin{array}{c}\text { Stand } \\
\text { composition, } \\
\%\end{array}$ & $\begin{array}{l}\text { Health } \\
\text { status }\end{array}$ & $\begin{array}{c}\text { Height, } \\
\text { m }\end{array}$ & $\begin{array}{l}\text { Diameter, } \\
\mathrm{cm}\end{array}$ & $\begin{array}{l}\text { Crown } \\
\text { projection } \\
\text { area, } \mathrm{m}^{2}\end{array}$ & $\begin{array}{l}\text { Crown } \\
\text { length, } \\
\mathrm{m}\end{array}$ & $\begin{array}{l}\text { Radial } \\
\text { growth, } \\
\mathrm{mm} / \mathrm{yr}\end{array}$ & $\begin{array}{l}\text { Age, } \\
\text { yrs }\end{array}$ \\
\hline \multicolumn{8}{|c|}{ Malinovka, $30 \times 80 \mathrm{~m}$; altitude (a.s.l.) $-179 \mathrm{~m} ;$ AWTS -3.0 units; density -1000 trees $/ \mathrm{ha}$} \\
\hline \multirow[b]{2}{*}{$56 \mathrm{~F}$} & living & $18.4 \pm 1.5$ & $24.1 \pm 2.2$ & $7.4 \pm 0.7$ & $10.5 \pm 0.9$ & $1.71 \pm 0.07$ & $67 \pm 3$ \\
\hline & $\begin{array}{c}\text { dead and } \\
\text { dying }\end{array}$ & $12.6 \pm 0.9$ & $17.6 \pm 1.2$ & - & - & $1.25 \pm 0.08$ & $76 \pm 3$ \\
\hline \multirow[b]{2}{*}{$26 \mathrm{~B}$} & living & $20.0 \pm 0.7$ & $24.5 \pm 2.2$ & $15.0 \pm 2.0$ & $10.9 \pm 0.6$ & $1.27 \pm 0.07$ & $70 \pm 2$ \\
\hline & $\begin{array}{c}\text { dead and } \\
\text { dying }\end{array}$ & $6.6 \pm 3.7$ & $35.4 \pm 7.1$ & - & - & - & $113 \pm 57$ \\
\hline \multirow[b]{2}{*}{$15 \mathrm{Sp}$} & living & $23.4 \pm 1.5$ & $30.6 \pm 3.4$ & $8.6 \pm 1.7$ & $13.0 \pm 1.4$ & $1.59 \pm 0.10$ & $81 \pm 4$ \\
\hline & $\begin{array}{c}\text { dead and } \\
\text { dying }\end{array}$ & $9.7 \pm 1.6$ & $14.5 \pm 4.0$ & - & - & $1.06 \pm 0.07$ & $65 \pm 12$ \\
\hline $3 \mathrm{~S}$ & living & $23.1 \pm 0.5$ & $31.2 \pm 3.1$ & $7.9 \pm 3.2$ & $12.1 \pm 0.8$ & $1.74 \pm 0.06$ & $69 \pm 7$ \\
\hline \multicolumn{8}{|c|}{ Itatka, $30 \times 50 \mathrm{~m}$; altitude (a.s.l.) - $152 \mathrm{~m} ;$ AWTS -1.8 units; density -625 trees $/$ ha } \\
\hline \multirow[b]{2}{*}{$73 \mathrm{~F}$} & living & $23.9 \pm 0.3$ & $30.4 \pm 0.7$ & $8.7 \pm 0.4$ & $12.7 \pm 0.3$ & $2.38 \pm 0.07$ & $66 \pm 1$ \\
\hline & $\begin{array}{c}\text { dead and } \\
\text { dying }\end{array}$ & $16.2 \pm 2.0$ & $28.0 \pm 1.9$ & - & - & $1.97 \pm 0.12$ & $78 \pm 2$ \\
\hline $16 \mathrm{~B}$ & living & $20.2 \pm 0.6$ & $19.5 \pm 1.0$ & $11.6 \pm 2.3$ & $9.8 \pm 0.5$ & $1.69 \pm 0.07$ & $62 \pm 2$ \\
\hline $7 \mathrm{Sp}$ & living & $24.0 \pm 1.2$ & $31.5 \pm 3.5$ & $14.9 \pm 3.5$ & $13.2 \pm 1.5$ & $2.14 \pm 0.11$ & $67 \pm 4$ \\
\hline $2 \mathrm{~S}$ & living & $20.3 \pm 0.5$ & $28.4 \pm 2.0$ & $9.7 \pm 0.5$ & $12.0 \pm 0.5$ & $2.28 \pm 0.13$ & $71 \pm 5$ \\
\hline $1 \mathrm{P}$ & living & 23.1 & 44.1 & 18.2 & 11.2 & $2.76 \pm 0.15$ & 75 \\
\hline $1 \mathrm{~A}$ & living & 24.3 & 19.2 & 3.4 & 12.1 & $1.94 \pm 0.19$ & 79 \\
\hline
\end{tabular}

Stand composition explication: F - Siberian fir; S - Siberian pine; Sp - Siberian spruce; $\mathrm{P}$ - Scots pine; B - Silver birch; A - Aspen.

\section{Reconstruction of stand history}

The forest use history of the respective sites was reconstructed taking into account the age structure of the communities, the species composition and the distribution of trees by height and diameter. The presence of traces from logging were also taken into account. Stumps were assessed with regard to tree species, the diameter at the ground level was measured and their density was calculated. The mapping of stumps on the SP Malinovka made it possible to estimate the degree of anthropogen- 
ic impact to the forest ecosystem. We calculated the number of sawed stumps and stumps formed as a result of the natural death of trees.

The processing of the material was carried out in the STATISTICA 10 program. In addition to the standard descriptive statistics, the non-parametric Mann-Whitney test and the Kruskal-Wallis test were used to test significance of the respective parameter with the level of $\mathrm{p}<0.05$.

Characterisation of type and intensity of the bark beetle infestation: non-spatial event analysis

We characterised the infestation by weight (originally denoted as thinning weight, $r G$ ratio) and type (originally denoted as thinning types, $N G$ ratio) [17]. The infestation weight reflects the intensity of the bark beetle attack on the stand level. The $N G$ ratio indicates the infestation type, for example, if trees with relatively larger or smaller diameter were killed by the bark beetle. Values below 1 indicate that especially strong trees were killed; values higher than 1 indicate that mostly trees with smaller diameter were affected. A value near 1 indicates that the proportion of removed stems was proportional to the removed basal area:

$$
\begin{gathered}
r G=\frac{G_{r}}{G_{t}} ; \\
N G=\frac{N_{r} / N_{t}}{G_{r} / G_{t}},
\end{gathered}
$$

where $r G$ - infestation weight; $G_{r}$ - removed basal area, $\mathrm{m}^{2} / \mathrm{ha} ; G_{t}-$ total basal area, $\mathrm{m}^{2} / \mathrm{ha}$; $N G$ - infestation type; $N_{r}$ - removed stem number; $N_{t}$ - total stem number.

Since the bark beetle is selective with regard to species, we elaborated $r G$ and $N G$ only for the fir tree population in each sample plot ( $r G_{-}$fir and $N G$ fir).

Analysis of the bark beetle infestation on spatial forest structure

We analysed the tree distribution pattern of the samples with the help of the univariate cumulative and non-cumulative distribution functions. With regard to recently conducted research of undisturbed fir forests in Mongolia [19], we initially assumed predominantly random tree distribution patterns on our fir forest sample plots. We assumed that the Polygraphus proximus invasion has changed some parameter of the horizontal tree distribution pattern in the fir forests and that we may find traces of a structural pattern of the infestation (e.g., attack on neighbouring trees). Based on previous studies and our assumptions, we tested the hypothesis of complete spatial randomness for all living trees, all living firs and dead firs. We used the square-root transformation of the univariate $K 11$-function, called univariate cumulative $L$-function $L(r)[10,45]$. The $95 \%$ confidence envelope was constructed using the Monte Carlo method [42]. A total of 999 Poisson patterns were simulated for each data set. The null hypothesis of this model assumes that the tree distributions of all plots follow a homogeneous Poisson process across the entire distance $[15,42]$ with $r_{\max }=14 \mathrm{~m}$. The pattern is defined as clumped, random or regular if the $L$-values at distance $r$ are greater than, equal to or lower than the confidence envelopes, respectively:

$$
L(r)=\sqrt{\frac{K(r)}{\pi}}-r,
$$

where $L(r)$ - univariate cumulative $L$-function, $L(r)=0$ for $r \geq 0 ; K(r)$ - the first derivative of Ripley's $K$-function; $\pi$ - mathematical constant; $r$ - distance, $\mathrm{m}$. 
Additionally, we cross-checked the results of the interpretation with the complementary univariate non-cumulative pair correlation function $\mathrm{g}(\mathrm{r})$ [45], which shows the non-cumulative classification. The simulations (999) were computed for deriving critical values for $\alpha=0.05$ for each data set:

$$
g(r)=\frac{d K(r)}{d r} /(2 \pi r),
$$

where $g(r)$ - univariate non-cumulative pair correlation function, $g(r)=1$ for $r \geq 0 ; d K$ - the density function of $K(r) ; d r-$ density, trees/ha.

Testing the hypothesis of spatial independence between living and dead/severely weakened fir trees after the Poligraphus proximus invasion

Additionally, we wanted to know if there is any significant spatial relation between living firs and firs that have been killed or severely weakened by the bark beetle. Therefore, we tested the spatial independence between these two groups with simulations that involved random shifts of one component pattern relative to the other, called toroidal shifts. We used the bivariate cumulative $L 12$-function $L 12(r)$ [45]. Additionally, we cross-checked the results for the interpretation with the complementary bivariate non-cumulative pair correlation function $g 12(r)$ [45]. Attraction, spatial independence or repulsion is indicated if the pair correlation function values at the distance $r$ are greater than, equal to or lower than the $95 \%$ confidence envelopes, respectively. The simulations (999) were computed for deriving critical values for $\alpha=0.05$ for each data set.

Spatial analysis of the relative dominance of trees species with the measure of surround $U_{i}$

In order to test our hypothesis that suppressed trees are more likely to be intensively attacked and killed by the bark beetle, we analysed the relative social status of the trees. The social status of a tree (relative dominance of suppression) depends on the individual tree neighbourhood. In the frame of this study, one objective is to assess the relative dominance with regard to tree species and tree health status with reference to Polygraphus proximus. The measure of surround $U_{i}$ is an index for classifying the size of tree $i$ in comparison to its next four neighbours. The original classification was presented by Gadow and Hui $[17,21]$. In our study, we applied the scaling according to Gradel and Mühlenberg [19] that was proposed in order to logically match the $U_{i}$ values to other index values of spatial forest structure (lower index values indicate a lower status of the respective parameter). With regard to $U_{i}$, it means that a relatively smaller size reference tree $i$ compared to a neighbour tree $j$ equals a classified value of 0 ; relatively larger size equals a classified value of 1 . For the calculation, see equation 6 (see Fig. 2 for examples):

$$
U_{i}=\frac{1}{4} \sum_{j=1}^{4} v_{j}
$$

where $U_{i}$ - index for classifying the size of tree $i, 0 \leq U_{i} \leq 1 ; v_{j}$ - the respective value of $i$ 's neighbour $j, 0 \leq v_{j} \leq 1$; $(0-$ neighbour $j$ is larger than the reference tree $i$, 1 - otherwise). 


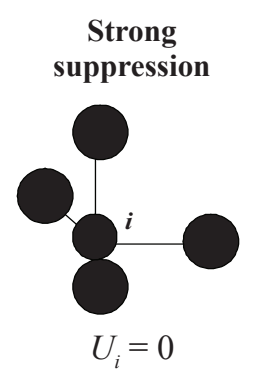

4 neighbours are larger than the reference tree $i$
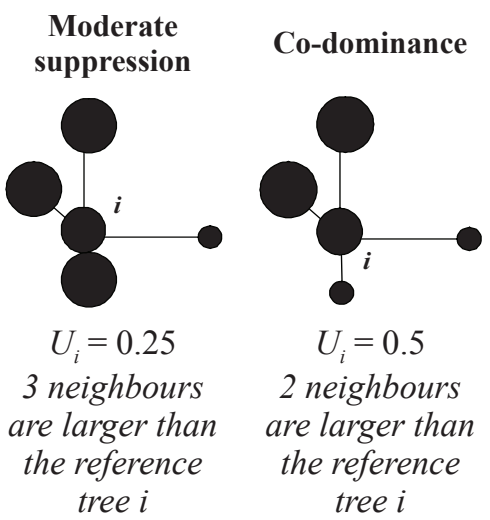

2 neighbours are larger than

the reference tree $i$

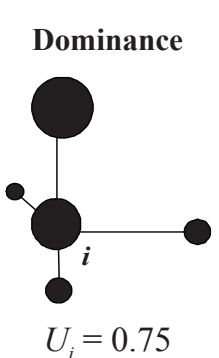

1 neighbour is larger than the reference tree $i$
Strong

dominance

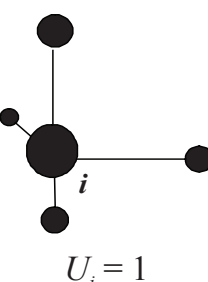

All neighbours

have smaller

diameter than the reference tree $i$

Fig. 2. A four-tree neighbourhood sample provides five options for the $U_{i}$ value (assessment of dominance); based on Gadow and Hui [17] and adjusted according to Gradel and Mühlenberg [19]

In order to get a realistic picture, we analysed the social status of each tree (relative dominance or suppression) in 2014, when the bark beetle infestation took place, and four years later in 2018. We compared the obtained values of living to dead/severely weakened trees. Diameter size for 2014 was calculated with the help of wood cores cut in 2018. The analysis was conducted with R-statistics 3.5.1 with the spatstat package [7].

\section{Results}

Status of basic stand structure as of 2018

The forest stand of the SP Itatka is part of a mixed forest stand with a predominance of Siberian fir and a significant participation of Silver birch. To less extend Siberian spruce and Siberian pine are also present (Table 1). The age structure allows us to distinguish two generations. The first generation consists of largely dead Silver birch over 100 years old. The age of the second generation ranges from 65 to 80 years. Consequently, the second generation appeared when the age of the first generation was 30 to 40 years. Given the location of the site near the village (up to $1 \mathrm{~km}$ ) and the time of establishment of the village of Itatka (1884), it can be assumed that the first generation arose on the site after the felling. Subsequently, under the canopy of the pioneer trees (birch), the dark conifers established. Since the site was periodically subjected to selective felling, the occasionally establishment of deciduous species there started again.

The stand of the SP Malinovka is also part of a mixed forest stand, but with a large participation of Siberian fir and a significant proportion of Silver birch. The composition also includes Siberian spruce and Siberian pine, rarely Scots pine and Aspen also occur. The age structure is homogeneous and consists of one generation of 60-70 years. Given that the site is located directly on the outskirts of the village Malinovka (established in 1891), it can be assumed that the first generation was cut down during the time of the establishment of the village in the form of clear-cutting. A continuous anthropogenic impact is indicated by the almost complete absence of dead trees on the SP Malinovka, while on the SP Itatka they are found for almost all tree species.

Despite the similar characteristics of the tree canopy, the model stands can be attributed to two different stages of the forest-forming process of fir forests. This is clearly seen in Fig. 3. The forest stand of the SP Itatka is at an earlier stage compared to the community of the SP Malinovka. Proof of this is the much greater density of 
a)

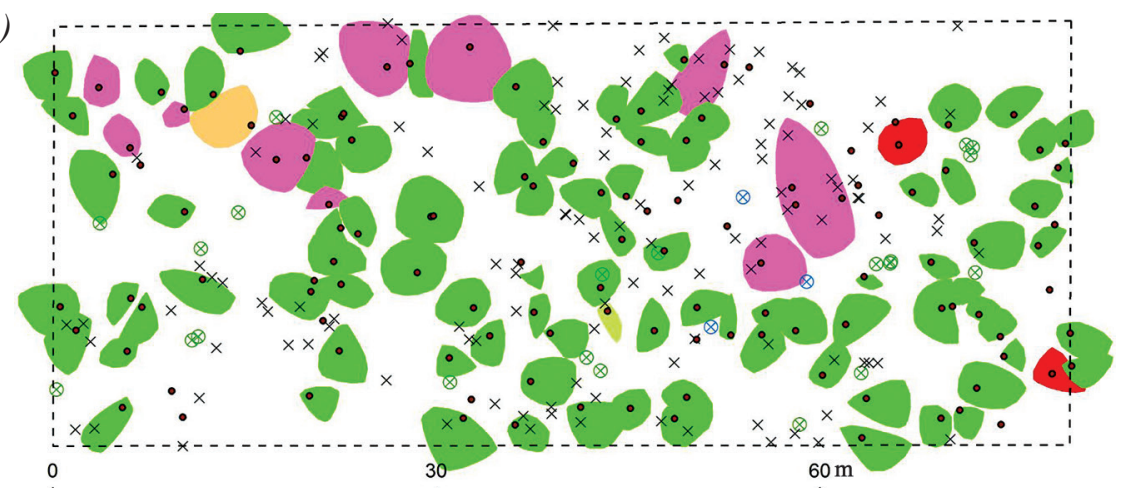

b)

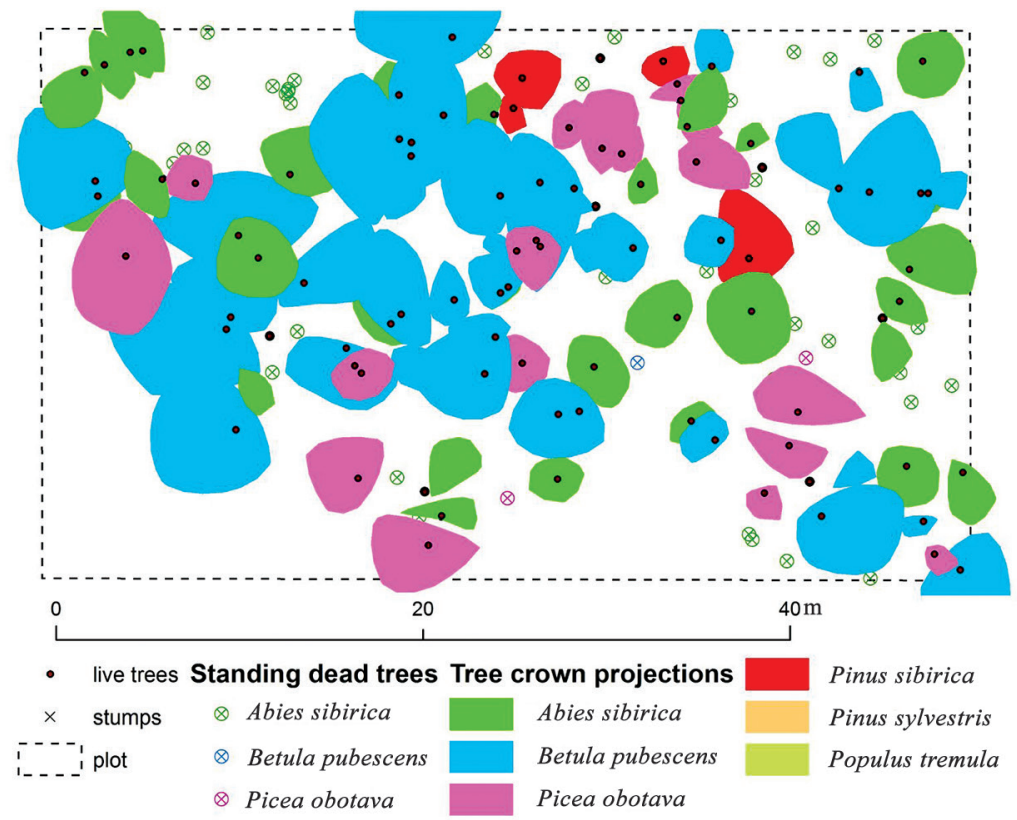

Fig. 3. Tree maps indicating positions of living trees, crown projections of living trees and trees recently killed by the invasive bark beetle: $a$ ) - SP Malinovka; $b$ ) - SP Itatka

the stand (37\%), with respectively smaller average values: height (23\%), diameter $(21 \%)$ and the value of the trunk growth $(28 \%)$ in living trees of Siberian fir. A distinctive feature is that the fir on the SP Itatka only goes to the first layer of the forest stand, and on the SP Malinovka, it has confidently taken a dominant position in the tree canopy. Thus, it is logical to assume that the forest stand of the SP Itatka is experiencing more stress due to more intense competition, and therefore, should be more affected by the impact of the invasive beetle. A comparison of the AWTS index (3.0 for Itatka and 1.8 for Malinovka) confirms this assumption.

Dead wood in the Malinovka stands

On the SP Malinovka, we also mapped all the stumps and it turned out that there are about $504 \mathrm{pcs} / \mathrm{ha}$. At the same time, $76 \%$ show characteristic traces of saws and only $24 \%$ originated as a result of breakdown, which indicates a natural origin. Fir accounts for the largest part (94\%), then birch (6\%). According to the degree of decomposition, $48 \%$ of stumps are classified into the second category, $26 \%$ to the third, $12 \%$ to the fourth, $6 \%$ to the fifth and $2 \%$ to the sixth. 
The diameter of the sawed stumps is $24.6 \pm 0.9 \mathrm{~cm}$, which is significantly (Mann-Whitney, test $\mathrm{p}=0.0001$ ) larger than the size of the stumps formed as a result of natural causes $(16.9 \pm 1.4 \mathrm{~cm})$. We found no significant differences in stump diameter with regard to the degree of decomposition (Kruskal-Wallis test, $p=0.4249$ ). The size of sawn stumps meets the generally accepted requirements for private construction wood, indicating something about the purpose of the logging on the site.

The impact of the four-eyed fir bark beetle at the stand level

Our analysis showed that on the SP Itatka, the height and diameter of fir trees killed or severely weakened in attacks by the four-eyed fir bark beetle were significantly lower than in live individuals (Mann-Whitney test, $p=0.0153$ and $p=0.0022$, respectively). With regard to tree age, no connection was found. Also, dead firs showed low growth of the trunk compared to living trees (Mann-Whitney test, $\mathrm{p}=0.0153$ ). Dead and severely weakened firs of the SP Malinovka also had lower height and diameter values compared to living trees (Mann-Whitney test, $p=0.0001$ and $p=0.0536$, respectively). The radial increment of dead/severely weakened firs was lower than that of living firs (Mann-Whitney test, $p=0.0025$ ). Certain parameters, such as the crown projection and length were not analysed since they cannot be compared to the same parameters of dead trees.

The height of the tree canopy on the SP Itatka is $16.86 \pm 0.61 \mathrm{~m}$ and the crowns of the trees begin at a height of $9.07 \pm 0.38 \mathrm{~m}$. Comparing the height of dead trees, it can be noted that fir grew to the middle of the crown space, but spruces did not survive the competition and immediately began to die. The height of the tree canopy on the SP Malinovka is $22.22 \pm 0.44 \mathrm{~m}$ and the crowns of the trees begin at a height of $10.86 \pm 0.41 \mathrm{~m}$. Comparing the height of the dead firs, it can be noted that they also grew to the middle of the crown space. The beginning and the process of ingrowth into the upper canopy is a critical time and the trees are more susceptible to external impacts.

The non-spatial event analysis showed that, considering only fir trees, the intensity was much stronger on the SP Itakta ( $r G$ fir with 0.375 ), although the effect of the infestation with regard to size classes was not too different in Malinovka and Itatka. However, the $N G$ ratio of fir ( $N G$ fir), shows that more often smaller firs rather than larger firs were affected by the infestation (Fig. 4).

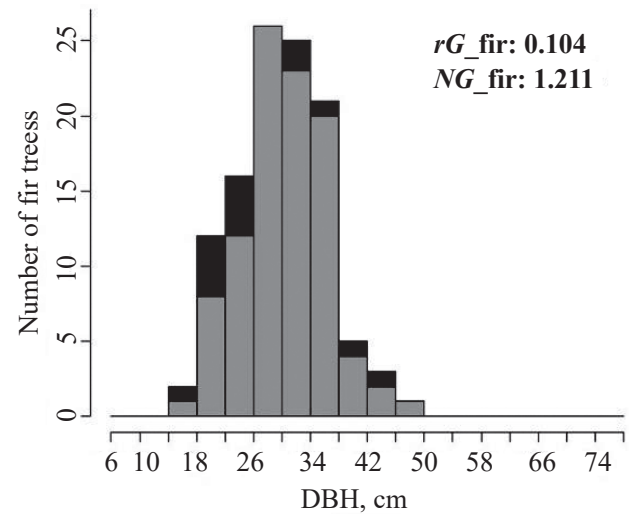

$a$

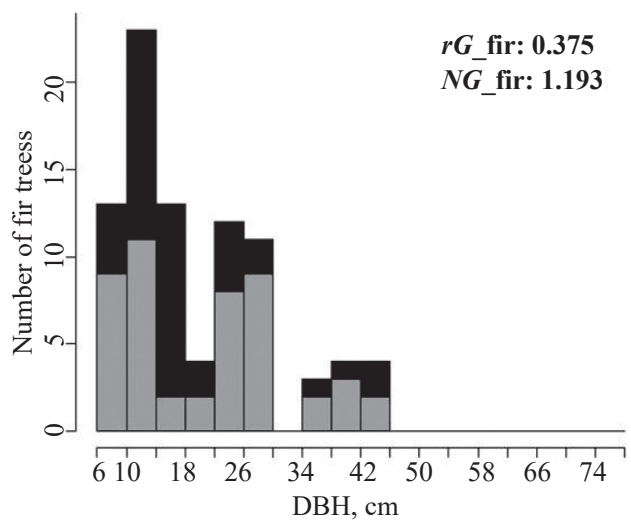

$b$

Fig. 4. Non-spatial event analysis of the RS Malinovka $(a)$ and Itatka $(b)$ : grey - fir trees that were not attacked; black - fir trees severely attacked; $r G_{-}$fir - infestation weight on fir trees; $N G \_$fir - infestation type on fir trees 
Relative dominance and suppression of tree species

The analysis of the social status of the trees showed, that individuals of Pinus sibirica are largely dominant, whereas the other three species are only co-dominant (Table 2).

Table 2

Overview of the species-specific classification of the social status of the trees in the SP Itatka and of fir trees killed or severally weakened by Polygraphus proximus

\begin{tabular}{|c|c|c|c|c|c|c|c|}
\hline \multirow{3}{*}{ SP } & \multirow{3}{*}{ Year } & \multicolumn{6}{|c|}{$U_{i}$} \\
\hline & & \multicolumn{4}{|c|}{ all trees (attacked and not attacked) } & \multicolumn{2}{|c|}{$\begin{array}{l}\text { trees severely attacked by } \\
\text { Polygraphus proximus }\end{array}$} \\
\hline & & $\begin{array}{l}\text { Pinus } \\
\text { sibirica }\end{array}$ & $\begin{array}{c}\text { Picea } \\
\text { obovata }\end{array}$ & $\begin{array}{c}\text { Betula } \\
\text { pendula }\end{array}$ & $\begin{array}{c}\text { Abies } \\
\text { sibirica }\end{array}$ & $\begin{array}{c}\text { Abies } \\
\text { sibirica* }\end{array}$ & $\begin{array}{c}\text { Abies } \\
\text { sibirica }^{* *}\end{array}$ \\
\hline \multirow{2}{*}{ Itatka } & 2014 & 0.813 & 0.526 & 0.578 & 0.435 & 0.486 & 0.481 \\
\hline & 2018 & 0.813 & 0.526 & 0.590 & 0.439 & 0.382 & 0.282 \\
\hline \multirow{2}{*}{ Malinovka } & 2014 & 0.750 & 0.531 & 0.300 & 0.572 & 0.438 & 0.250 \\
\hline & 2018 & 0.750 & 0.500 & 0.300 & 0578 & 0.458 & 0.375 \\
\hline
\end{tabular}

* Killed or severely weakened with participation of Polygraphus proximus.

** Killed or severely weakened only by Polygraphus proximus.

Classification of $U_{i}$ values: $U_{i}=0$ (strong suppression); $U_{i}=0.25$ (moderate suppression); $U_{i}=0.5$ (co-dominance); $U_{i}=0.75$ (dominance); $U_{i}=1$ (strong dominance); The classification is based on Gadow and Hui [17] and adjusted according to Gradel and Mühlenberg [19].

Interestingly, the social status of fir trees killed or severely weakened only by Polygraphus proximus was much lower than the status of all fir trees of the SP Malinovka. In the SP Itakta, however, the status of all groups was relatively similar in 2014, but in 2018, the status of all fir trees had become clearly higher than that of killed/severely weakened trees. Overall, the results suggest that suppressed firs are more susceptible to being killed by the bark beetle. Also, in the SP Itatka, the social status of the attacked trees decreased further. In the SP Malinovka, it slightly increased, but the number of attacked individuals is relatively low compared to the SP Itatka, which lowers the relevance of the results of the SP Malinovka.

The impact of the four-eyed fir bark beetle on the horizontal tree distribution pattern

Spatial distribution of the living tree population (all species) was evaluated as being mostly random over the entire distance of the SP Malinovka (Fig. 5).

However, on the SP Itatka (Fig. 6), a clumped distribution pattern of the entire tree population was indicated after a distance of $6 \mathrm{~m}$ by the univariate cumulative $L(r)$. Both figures 5 and 6 show dead or severely weakened firs; death caused or triggered by the four-eyed fir bark beetle.

On both sample plots, the hypothesis of complete spatial randomness of the tree distribution pattern of the remained living firs was accepted by the analysis with the univariate cumulative $L$-function $L(r)$. The univariate non-cumulative pair correlation function $g(r)$, however, indicated a clumped distribution of the living firs at a distance of $1 \mathrm{~m}$ on the SP Itatka. In contrast to the distribution pattern of living firs, the pattern of dead and severely weakened firs by the four-eyed 
fir bark beetle was significantly clumped over short (SP Itatka and SP Malinovka) or, to some extent, larger distances (SP Itatka), irrespective of the succession stage. This finding coincides with visual observations in other stands - that attacked trees are to some extent grouped. However, the hypothesis of spatial independence of the tree positions of living and dead/severely weakened firs was accepted for both plots.
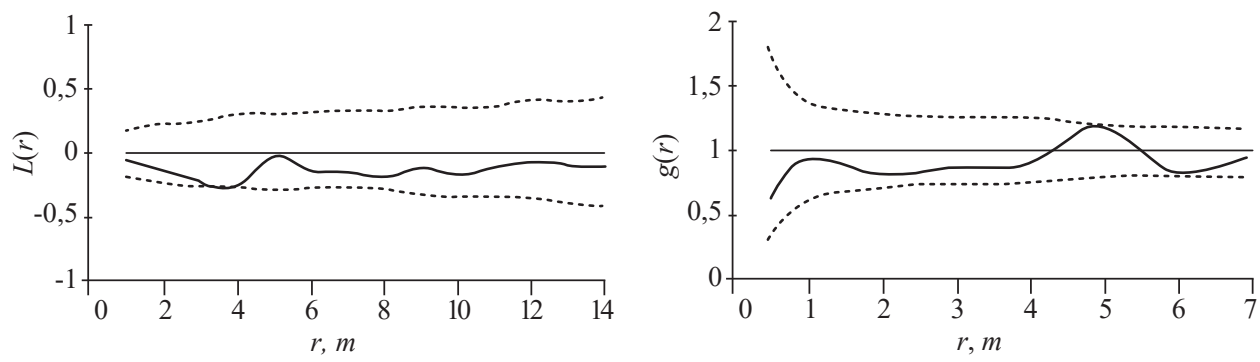

Test of spatial randomness - all living trees
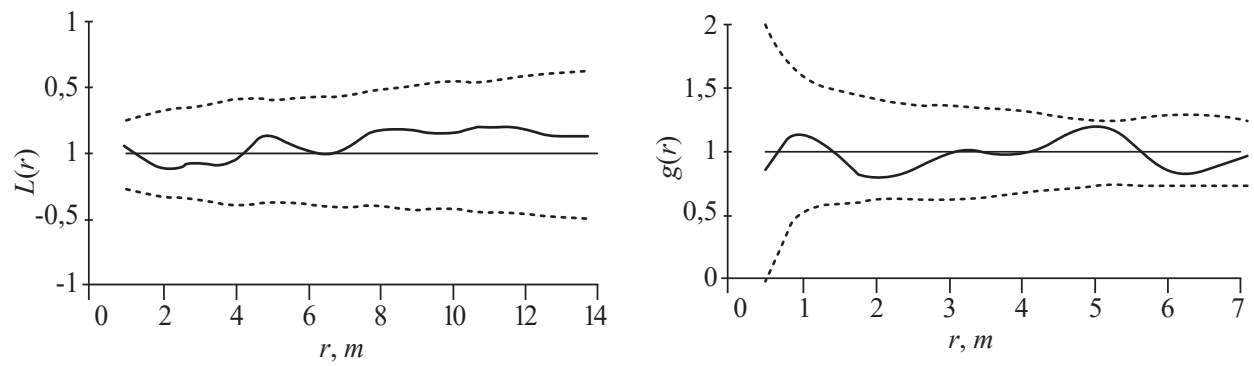

Test of spatial randomness - living firs
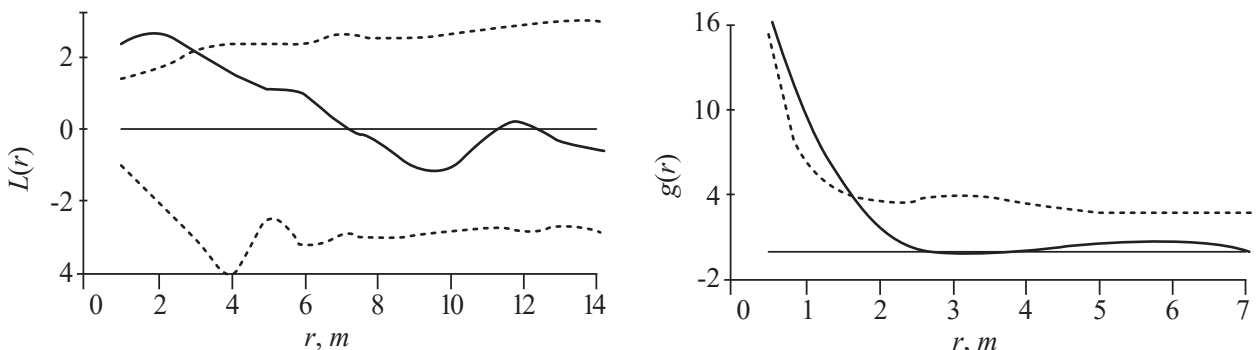

Test of spatial randomness - dead/severely weakened firs
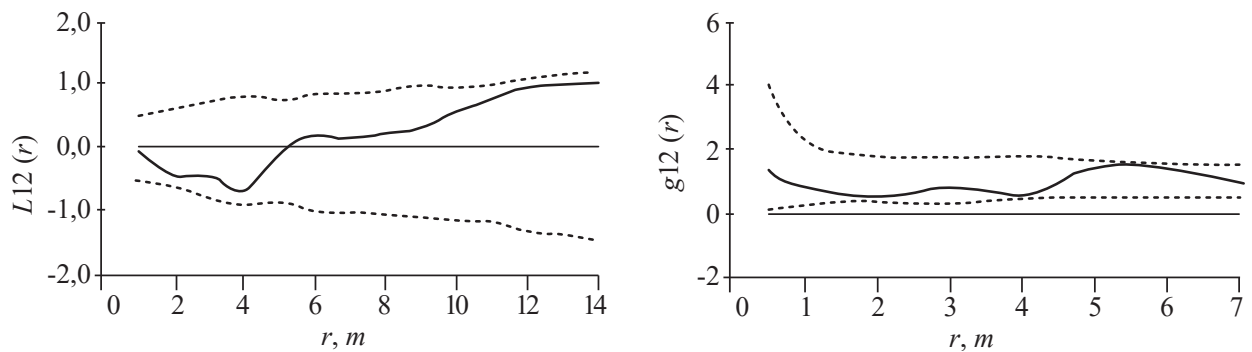

Test of spatial independence - living firs versus dead/dying firs

Fig. 5. $L$-functions and pair correlation functions of the analyses of the horizontal spatial forest structure of the SP Malinovka 

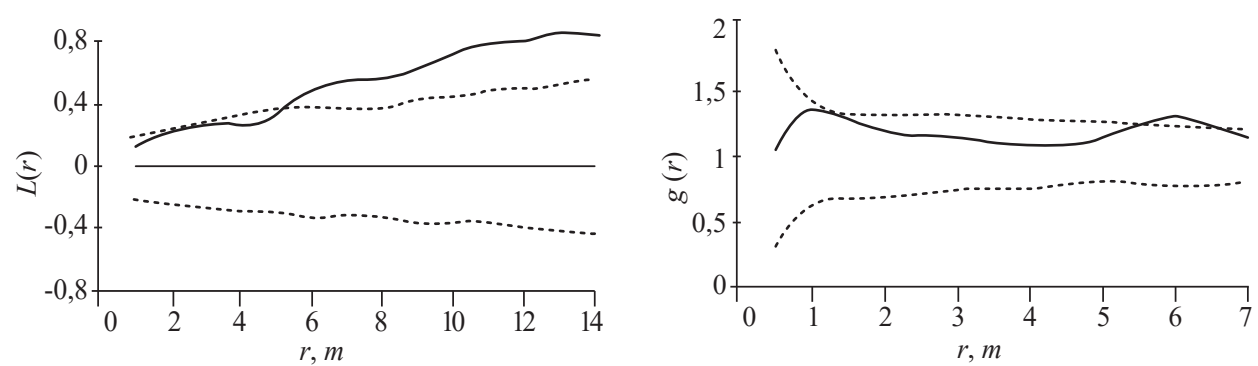

Test of spatial randomness - all living trees
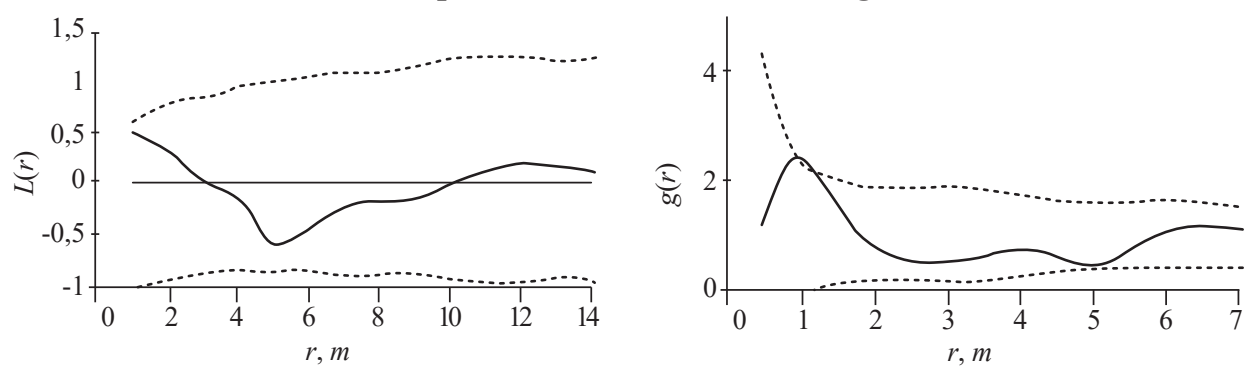

Test of spatial randomness - living firs
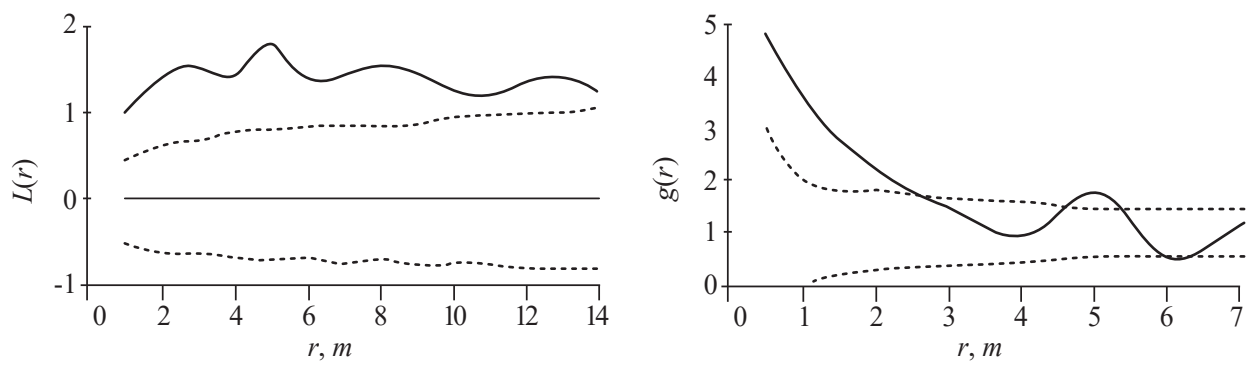

Test of spatial randomness - dead/severely weakened firs
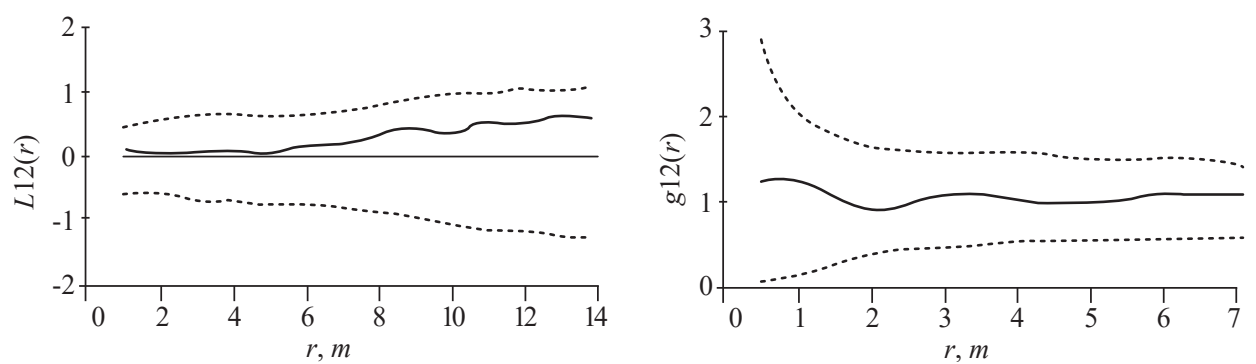

Test of spatial independence - living firs versus dead/dying firs

Fig. 6. $L$-functions and pair correlation functions of the analyses of the horizontal spatial forest structure of the SP Itatka

\section{Discussion}

Based on our results, we discuss the preferences and pattern of Polygraphus proximus attacks.

Compared to living firs, dead trees exhibited, on average, lower height and diameter values. These features are noted by other authors [8], which allows us to consider the tree diameter as being a main indicator of susceptibility to damage at 
the stand level [9]. However, larger diameters usually exhibit thicker bark. Therefore, we assume that bark thickness may play a role in the susceptibility of the trees. Bark protects the tree against external abiotic and biotic disturbances. For example, tree species with thicker bark are considered to be better protected against fire damage than species with thinner bark [32]. Recently, the close association of fire-driven ecosystems and tree species with thick bark at a global scale across different vegetation zones was shown [35]. Fir and spruce are climax species with rather thin bark. This may be due to the fact that fires in dark taiga ecosystems are naturally less common compared to disturbance-prone larch and birch forests [19]. For a bark beetle, however, bark represents a barrier that it has to overcome. Another barrier for the beetle is resin. Vital and strong trees produce more resin and are, therefore, better protected. In this context, vitality and most likely diameter size play a role as well. Since diameter size plays a crucial role for susceptibility against the beetle, the development stage of the stand is also important. Fir stands with left-sided ontogenetic structure appear to be more resistant [3].

Our results suggest that the most critical period is when the fir trees grow into the upper layer of the stand. At this stage, Polygraphus proximus is able to cause maximum damage and interrupt the forest-forming process of fir or, if there is a sufficient amount of viable undergrowth of fir, roll back the succession cycle of its dominance for several decades. In any case, the decrease in canopy cover stimulates the growth of saplings [38]. This shows how insect outbreaks can be a driver of forest dynamics.

Suppressed trees are more frequently successfully attacked and weakened by the bark beetle

Our results of the spatial analysis are consistent with previously established features of the impact of Polygraphus proximus and indicate the predominant influence of the invader on suppressed trees [4]. A recent generalisation on the invasion of bark beetle Phloeosinus aubei in the Czech Republic [16], which began in the 1950s, also suggests that mainly trees with reduced viability were damaged. The nature of the impact of Polygraphus proximus in the periods between outbreaks of mass reproduction is similar. Generally, two types of infestations can clearly be distinguished in the activity of bark beetles. The first type refers to the normal population activity; in our case the polygraph kills the weakest trees. The second type is when the entire stand is weakened. Then, the beetle successfully attacks those trees that were recently viable and could withstand it. In years of mass reproduction, the beetle is able to damage vital trees, as it was shown by the example of the analysis of the social status of fir trees on the SP Itatka. Therefore, the four-eyed fir bark beetle can be considered as a dangerous pest of the forest. It needs to be understood that periods of mass reproduction are due to the general weakening of stands related to climate change or extreme weather events [40]. During such periods (for example droughts), almost all the trees in the stands are weakened to some extent.

The infestation is a disturbance that influences the horizontal tree distribution pattern

It appears that uneven-aged near-natural fir forests mostly exhibit random tree distribution patterns. This, however, also depends on the development stage and disturbance history. Younger stands will be more clumped; regeneration often exhibits clumped distribution. Random or partly-clumped tree distribution patterns were found in near-natural fir-beech forests and spruce forests in Central Europe [20, 23]. Random tree distribution patterns were found in undisturbed Mongolian dark taiga for- 
ests $[2,19]$. Our data confirmed this to some extend for the respective samples of Siberian fir forests in Tomsk region. It is well known that different disturbances affect forest structure [29], but there are hardly any studies available that evaluated the impact of a bark beetle infestation on spatial forest structure. We found that the impact of Polygraphus proximus on fir trees tends to occur in clusters. This was repeatedly recorded in the stands that were subjected to the initial attack of the invader. Stereńczak et al. [41] found that the dying of spruce trees during the pandemic mass reproduction of the bark beetle Ips typographus in the Białowieża Forest took place in groups.

Based on our results, it may be possible to develop a scheme for zoning the secondary (invasive) range of Polygraphus proximus according to the degree of its susceptibility. This zonation may help to implement required forestry measures for increasing stand stability and resilience against potential infestations. A somewhat similar model approach, that included some characteristics of forest stands, has been carried out with respect to Mountain pine beetle infestations in Western Canada [14].

\section{Conclusion}

Our analysis showed that both height and diameter of fir trees killed in attacks by the four-eyed fir bark beetle were significantly lower than in live individuals. Also, dying firs showed lower growth of the trunk compared to vital living trees. Comparing the height of dead trees, it can be noted that firs grew to the middle of the crown space, but spruce did not survive the competition and immediately begin to die. The analysis of the social status of the trees during the infestation in 2014 showed that the status of fir trees seriously attacked or killed by Polygraphus proximus is relatively even or lower (more suppressed) than the status of all fir trees. Overall, Polygraphus proximus attacks are concentrated on relatively smaller and neighbouring trees. In contrast to the distribution pattern of living firs, the pattern of dying firs, attacked by the four-eyed fir bark beetle, was significantly clumped over short distances (SP Itatka and SP Malinovka). This finding coincides with visual observations in other stands, that is, dead trees are to some extent grouped and are in close proximity to each other. Some parameters analysed in this study may be useful for forecasting or modelling stand susceptibility of fir stands against Polygraphus proximus in the region, which in turn, would allow implementation of management practices for increasing stand stability or resilience against infestations.

\section{REFERENCES}

1. Гниненко Ю.И., Ширяева Н.В., Шуров В.И. Самшитовая огневка - новый инвазивный организм в лесах российского Кавказа // Карантин растений. Наука и практика. 2014. № 1(7). C. 32-39. [Gninenko Yu.I., Shiryaeva N.V., Shchurov V.I. The Box Tree Moth A New Invasive Pest in the Caucasian Forests. Karantin rasteniy. Nauka i praktika [Plant Health. Research and Practice], 2014, no. 1(7), pp. 32-39].

2. Градель А., Воинков А.А., Алтаев А.А., Энхтуяа Б. Пространственно-структурный анализ ненарушенной темнохвойной тайги в южной таежной зоне и интервальная оценка темнохвойного смешанного леса в горной лесостепной зоне (Монголия) // Тр. Кубан. гос. аграр. ун-та. 2018. № 4(73). С. 36-44. [Gradel A., Voinkov A.A., Altaev A.A., Enkhtuya B. A Spatio-Structural Analysis of Intact Dark Taiga in the Southern Taiga Zone and an Interval Assessment of a Dark Conifer Mixed Forest in the Mountain Forest Steppe Zone (Mongolia). Trudy Kubanskogo gosudarstvennogo agrarnogo universiteta [Proceedings of 
the Kuban State Agricultural University], 2018, vol. 4(73), pp. 36-44]. DOI: 10.21515/19991703-73-36-44

3. Дебков Н.М. Влияние уссурийского полиграфа на онтогенетическую структуру пихтовых лесов Западной Сибири // Изв. вузов. Лесн. журн. 2018. № 5. С. 116-125. [Debkov N.M. Four-Eyed Fir Bark Beetle Influence on the Ontogenetic Structure of Fir Forests in Western Siberia. Lesnoy Zhurnal [Russian Forestry Journal], 2018, no. 5, pp. 116125]. DOI: $10.17238 /$ issn0536-1036.2018.5.116, URL: http://lesnoizhurnal.ru/upload/iblock/ d21/116 125.pdf

4. Дебков Н.М. Закономерности изменения структуры пихтовых лесов, поврежденных в результате инвазии уссурийского полиграфа // Лесотехн. журн. 2018. Т. 8, № 1(29). C. 13-22. [Debkov N.M. Regularities of Changes in the Structure of Fir Forests Damaged as a Result of the Invasion of Polygraphus proximus. Lesotekhnicheskiy zhurnal [Forestry Engineering Journal], 2018, vol. 8, no. 1(29), pp. 13-22]. DOI: 10.12737/article 5ab0dfbacbcc 16.33568232

5. Aukema J.E., McCullough D.G., Von Holle B., Liebhold A.M., Britton K., Frankel S.J. Historical Accumulation of Nonindigenous Forest Pests in the Continental United States. BioScience, 2010, vol. 60, iss. 11, pp. 886-897. DOI: 10.1525/bio.2010.60.11.5

6. Bacon S.J., Bacher S., Aebi A. Gaps in Border Controls are Related to Quarantine Alien Insect Invasions in Europe. PLoS ONE, 2012, vol. 7(10), art. e47689. DOI: 10.1371/ journal.pone.0047689

7. Baddeley A., Rubak E., Turner R. Spatial Point Patterns: Methodology and Applications with R. London, CRC Press, 2015. 828 p.

8. Balzotti C.S., Asner G.P. Episodic Canopy Structural Transformations and Biological Invasion in a Hawaiian Forest. Frontiers in Plant Science, 2017, vol. 8, art. 1256. DOI: $\underline{10.3389 / \text { fpls.2017.01256 }}$

9. Bellahirech A., Branco M., Catry F.X., Bonifácio L., Sousa E., Ben Jamâa M.L. Site- and Tree-Related Factors Affecting Colonization of Cork Oaks Quercus suber L. by Ambrosia Beetles in Tunisia. Annals of Forest Science. 2019, vol. 76, iss. 2, art. 45. DOI: 10.1007/s13595-019-0815-1

10. Besag J. Contribution to the Discussion of Dr. Ripley's Paper. Journals of the Royal Statistical Society, 1977, vol. B39, pp. 193-195.

11. Binimelis R., Born W., Monterroso I., Rodríguez-Labajos B. Socio-Economic Impact and Assessment of Biological Invasions. Biological Invasions. Ed. by W. Nentwig. Berlin, Springer, 2007, pp. 331-347. DOI: 10.1007/978-3-540-36920-2_19

12. Bobiec A. Living Stands and Deadwood in the Białowieża Forest: Suggestions for Restoration Management. Forest Ecology and Management, 2002, vol. 165, iss. 1-3, pp. 125-140. DOI: $10.1016 /$ S0378-1127(01)00655-7

13. Born W., Rauschmayer F., Bräuer I. Economic Evaluation of Biological Invasions - A Survey. Ecological Economics, 2005, vol. 55, iss. 3, pp. 321-336. DOI: 10.1016/j. ecolecon.2005.08.014

14. Coggins S.B., Coops N.C., Wulder M.A. Initialization of an Insect Infestation Spread Model Using Tree Structure and Spatial Characteristics Derived from High Spatial Resolution Digital Aerial Imagery. Canadian Journal of Remote Sensing, 2008, vol. 34, iss. 6, pp. $485-502$. DOI: $10.5589 / \mathrm{m} 08-073$

15. Corral-Rivas J., Pommerening A., Gadow K.V., Stoyan D. An Analysis of Two Directional Indices for Characterizing the Spatial Distribution of Forest Trees. Models of Tree Growth and Spatial Structure for Multispecies, Uneven-Aged Forests in Durango (Mexico). Göttingen, Cuvillier, 2006, pp. 119-134.

16. Fiala T., Holuša J. Occurrence of the Invasive Bark Beetle Phloeosinus aubei on Common Juniper Trees in the Czech Republic. Forests, 2019, vol. 10, iss. 1, art. 12. DOI: $\underline{10.3390 / \mathrm{f} 10010012}$ 
17. Gadow K., Zhang C.Y., Wehenkel C., Pommerening A., Corral-Rivas J., Korol M., Myklush S., Hui G.Y., Kiviste A., Zhao X.H. Forest Structure and Diversity. Continuous Cover Forestry. Ed. by Pukkala T., Gadow K. Dordrecht, Springer, 2012, pp. 29-83. DOI: $10.1007 / 978-94-007-2202-622$

18. Gradel A., Ammer C., Ganbaatar B., Nadaldorj O., Dovdondemberel B., Wagner S. On the Effect of Thinning on Tree Growth and Stand Structure of White Birch (Betula platyphylla Sukaczev) and Siberian Larch (Larix sibirica Ledeb.) in Mongolia. Forests, 2017, vol. 8, iss. 4, art. 105. DOI: $10.3390 / \mathrm{f} 8040105$

19. Gradel A., Mühlenberg M. Spatial Characteristics of Near-Natural Mongolian Forests at the Southern Edge of the Taiga. Allgemeine Forst- und Jagd-Zeitung, 2011, vol. 182, no. $3 / 4$, pp. $40-52$.

20. Hofmeister Š., Svoboda M., Souček J., Vacek S. Spatial Pattern of Norway Spruce and Silver Fir Natural Regeneration in Uneven-Aged Mixed Forests of Northeastern Bohemia. Journal of Forest Science, 2008, vol. 54, iss. 3, pp. 92-101. DOI: 10.17221/2/2008-JFS

21. Hui G. Studies on the Application of Stand Spatial Structure Parameters Based on the Relationship of Neighborhood Trees. Beijing Linye Daxue Xuebao [Journal of Beijing Forestry University], 2013, vol. 35(4), pp. 1-8.

22. Hui G.Y., Hu Y.B. Measuring Species Spatial Isolation in Mixed Forests. Forest Research, 2001, vol. 14(1), pp. 23-27. DOI: 10.3321/j.issn:1001-1498.2001.01.004

23. Janík D., Adam D., Hort L., Král K., Šamonil P., Unar P., Vrška T. Tree Spatial Patterns of Abies alba and Fagus sylvatica in the Western Carpathians over 30 Years. European Journal of Forest Research, 2014, vol. 133, iss. 6, pp. 1015-1028. DOI: 10.1007/ s10342-014-0819-1

24. Kenis M., Auger-Rozenberg M.-A., Roques A., Timms L., Péré C., Cock M.J.W., Settele J., Augustin S., Lopez-Vaamonde C. Ecological Effects of Invasive Alien Insects. Biological Invasions, 2009, vol. 11, no. 1, pp. 21-45. DOI: 10.1007/s10530-008-9318-y

25. Kharuk V.I., Im S.T., Petrov I.A., Yagunov M.N. Decline of Dark Coniferous Stands in Baikal Region. Contemporary Problems of Ecology, 2016, vol. 9, no. 5, pp. 617625. DOI: $10.1134 / \mathrm{S} 1995425516050073$

26. Kharuk V.I., Im S.T., Ranson K.J., Yagunov M.N. Climate-Induced Northerly Expansion of Siberian Silkmoth Range. Forests, 2017, vol. 8, iss. 8, art. 301. DOI: 10.3390/ $\underline{\mathrm{f} 0080301}$

27. Kraft N.J.B., Ackerly D.D. Functional Trait and Phylogenetic Tests of Community Assembly across Spatial Scales in an Amazonian Forest. Ecological Monographs, 2010, vol. 80, no. 3, pp. 401-422.

28. Krivets S.A., Bisirova E.M., Kerchev I.A., Pats E.N., Chernova N.A. Transformation of Taiga Ecosystems in the Western Siberian Invasion Focus of Four-Eyed Fir Bark Beetle Polygraphus proximus Blandford (Coleoptera: Curculionidae, Scolytinae). Russian Journal of Biological Invasions, 2015, vol. 6, iss. 2, pp. 94-108. DOI: 10.1134/S2075111715020058

29. Kuuluvainen T., Grenfell R. Natural Disturbance Emulation in Boreal Forest Ecosystem Management - Theories, Strategies, and a Comparison with Conventional Even-Aged Management. Canadian Journal of Forest Research, 2012, vol. 42(7), pp. 1185-1203. DOI: $\underline{10.1139 / \mathrm{x} 2012-064}$

30. Larsson T., Angelstam P., Balent G., Barbati A., Bijlsma R., Boncina A. et al. Biodiversity Evaluation Tools for European Forests. Ecological Bulletins, 2001, no. 50, pp. 1-237.

31. Lei X., Lu Y., Peng C., Zhang X., Chang J., Hong L. Growth and Structure of Semi-Natural Larch-Spruce-Fir (Larix olgensis - Picea jezoensis-Abies nephrolepis) Forests in Northeast China: 12-Year Result after Thinning. Forest Ecology and Management, 2012, vol. 240, iss. 1-3, pp. 165-177. DOI: $10.1016 /$ j.foreco.2006.12.019

32. Martinsson O., Lesinski J.A. Siberian Larch: Forestry and Timber in a Scandinavian Perspective. Bispgården, JiLU Jämtland County Council, Institute of Rural Development, 2007. $90 \mathrm{p}$. 
33. Naumburg E., DeWald L.E. Relationships between Pinus ponderosa Forest Structure, Light Characteristics, and Understorey Graminoid Species Presence and Abundance. Forest Ecology and Management, 1999, vol. 124, iss. 2-3, pp. 205-215. DOI: 10.1016/S0378$1127(99) 00067-5$

34. Pastorella F., Paletto A. Stand Structure Indices as Tools to Support Forest Management: An Application in Trentino Forests (Italy). Journal of Forest Science, 2013, vol. 59, pp. 159-168. DOI: $10.17221 / 75 / 2012-J F S$

35. Pellegrini A.F., Anderegg W.R.L., Paine C.E.T., Hoffmann W.A., Kartzinel T., Rabin S.S., Sheil D., Franco A.C., Pacala S.W. Convergence of Bark Investment According to Fire and Climate Structures Ecosystem Vulnerability to Future Change. Ecology Letters, 2017, vol. 20, iss. 3, pp. 307-316. DOI: $10.1111 /$ ele.12725

36. Pretzsch H. Analysis and Modeling of Spatial Stand Structures. Methodological Considerations Based on Mixed Beech-Larch Stands in Lower Saxony. Forest Ecology and Management, 1997, vol. 97, iss. 3, pp. 237-253. DOI: 10.1016/S0378-1127(97)00069-8

37. Rinn F. TSAP V3.5. Computer Program for Tree-Ring Analysis and Presentation. Heidelberg, Frank Rinn Distribution, 1996. 264 p.

38. Rozendaal D.M.A., Kobe R.K. A Forest Tent Caterpillar Outbreak Increased Resource Levels and Seedling Growth in a Northern Hardwood Forest. PLoS ONE, 2016, vol. 11, art. e0167139. DOI: 10.1371/journal.pone.0167139

39. Sallabanks R., Riggs R.A., Cobb L.E. Bird Use of Forest Structural Classes in Grand Fir Forests of the Blues Mountains, Oregon. Forest Science, 2002, vol. 48, iss. 2, pp. 311-321. DOI: $10.1093 /$ forestscience/48.2.311

40. Stephenson N.L., Das A.J., Ampersee N.J., Bulaon B.M., Yee J.L. Which Trees Die during Drought? The Key Role of Insect Host-Tree Selection. Journal of Ecology, 2019, vol. 107, iss. 5, pp. 2383-2401. DOI: $\underline{10.1111 / 1365-2745.13176}$

41. Stereńczak K., Mielcarek M., Modzelewska A., Kraszewski B., Fassnacht F.E., Hilszczański J. Intra-Annual Ips typographus Outbreak Monitoring Using a Multi-Temporal GIS Analysis Based on Hyperspectral and ALS Data in the Białowieża Forests. Forest Ecology and Management, 2019, vol. 442, pp. 105-116. DOI: 10.1016/j.foreco.2019.03.064

42. Stoyan D., Stoyan H. Fractals, Random Shapes and Point Fields. Chichester, Wiley, 1994. 389 p.

43. Straw N.A., Williams D.T., Kulinich O., Gninenko Y.I. Distribution, Impact and Rate of Spread of Emerald Ash Borer Agrilus planipennis (Coleoptera: Buprestidae) in the Moscow Region of Russia. Forestry, 2013, vol. 86, iss. 5, pp. 515-522. DOI: $10.1093 /$ forestry/cpt031

44. Sustainable Forest Management. Ed. by J.L. Innes, A.V. Tikina. London, Routledge, 2016. $396 \mathrm{p}$.

45. Wiegand T., Moloney K.A. Rings, Circles, and Null-Models for Point Pattern Analysis in Ecology. Oikos, 2004, vol. 104, iss. 2, pp. 209-229. DOI: 10.1111/j.0030$\underline{1299.2004 .12497 . x}$

46. Zirlewagen D., Wilpert K. Modeling Water and Ion Fluxes in a Highly Structured, Mixed-Species Stand. Forest Ecology and Management, 2001, vol. 143, iss. 1-3, pp. 27-37. DOI: $10.1016 / \mathrm{S} 0378-1127(00) 00522-3$

\section{РЕКОНСТРУКЦИЯ ИСТОРИИ ДРЕВОСТОЕВ И ОЦЕНКА ВОЗДЕЙСТВИЯ ИНВАЗИВНОГО КОРОЕДА В ПИХТОВЫХ ЛЕСАХ С ПОМОЩЬЮ АНАЛИЗА ПРОСТРАНСТВЕННОЙ СТРУКТУРЫ}

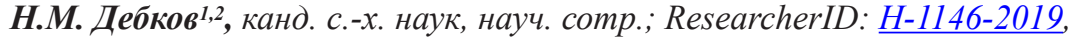
ORCID: https://orcid.org/0000-0003-3791-0369

A. Градель ${ }^{3,4}$, д-р наук, консультант по лесному делу; ResearcherID: AAK-1808-2020, ORCID: https://orcid.org/0000-0002-6298-4151 
A.A. Алейников ${ }^{5}$ канд. биол. наук, ст. науч. сотр.; ResearcherID: K-1285-2017, ORCID: https://orcid.org/0000-0002-5715-8488

${ }^{1}$ Институт мониторинга климатических и экологических систем СО РАН, просп. Академический, д. 10/3, г. Томск, Россия, 634055; e-mail: nikitadebkov@yandex.ru

${ }^{2}$ Национальный исследовательский Томский государственный университет, просп. Ленина, 36, г. Томск, Россия, 634050; e-mail: nikitadebkov@yandex.ru

${ }^{3}$ Международная консалтинговая компания по лесному делу «Градель», Якобштрассе, д. 12, Герлиц, Германия, 02826; e-mail: agradel@jpberlin.de

${ }^{4}$ Факультет лесного хозяйства и лесной экологии, Гёттингенский университет имени Георга-Августа, Бюзгенвег, д. 5, Гёттинген, Германия, 37077

5Центр по проблемам экологии и продуктивности лесов РАН, ул. Профсоюзная, д. 84/32, стр. 14, Москва, Россия, 117997; e-mail: aaacastor@gmail.com

На сегодняшний день в России самой масштабной и разрушительной инвазией ксилофагов в лесные экосистемы является массовое размножение уссурийского полиграфа (Polygraphus proximus Blandf.) в пихтовых (Abies sibirica Ledeb.) лесах. Цель исследования - изучение пространственной структуры пихтовых лесов и их трансформаций под воздействием уссурийского полиграфа в его вторичном (инвазивном) ареале распространения. Было выбрано 2 модельных пихтарника (около сел Итатка и Малиновка) в Томской области. Оба древостоя представляют собой естественные насаждения на участках, где отмечена лесозаготовительная деятельность, которая была вызвана образованием этих населенных пунктов во второй половине XIX в. Для сбора непространственных и пространственных данных использовали технологию Field-Map. Анализ показал, что высота, диаметр и радиальный прирост ствола пихт, погибших или сильно ослабленных при атаках уссурийского полиграфа, значительно ниже, чем у живых особей. Социальный статус пихт, подвергшихся серьезному нападению или уже погибших от Polygraphus proximus, обозначен индексом $U_{i}$ как умеренно угнетенный. Установленно, что в отличие от живых пихт размещение погибших деревьев было в значительной мере сгруппировано на коротких расстояниях (около 1 м). Данный вывод совпадает с визуальными наблюдениями на других участках, где погибшие деревья были сгруппированы. Тем не менее гипотеза пространственной независимости позиций живых и погибших пихт была принята для обоих участков.

Финансирование: исследование профинансировано Российским фондом фундаментальных исследований и правительством Томской области, грант № 16-44-700782 и выполнено в рамках государственного задания Центра по проблемам экологии и продуктивности лесов Российской академии наук (№ AАAА-A18-118052400130-7).

Для цитирования: Debkov N.M., Gradel A., Aleinikov A.A. Reconstruction of Stand History and Impact Evaluation of an Invasive Bark Beetle in Siberian Fir Forests with the Help of Spatial Structure Analysis // Изв. вузов. Лесн. журн. 2020. № 3. C. 24-41. DOI: 10.37482/0536-1036-2020-3-24-41

Ключевые слова: инвазии насекомых, Polygraphus proximus Blandf., Abies sibirica Ledeb., смертность деревьев, пространственно-временные характеристики.

Поступила 21.07.19 / Received on July 21, 2019 